\title{
Solid Waste Management and Incineration Practice: A Study of Bangladesh
}

\author{
Muhammad Saidur Rahman, Jahangir Alam \\ Department of Electrical \& Electronic Engineering, Pundra University of Science \& Technology, Bogura, Bangladesh \\ Email: saeed_hamim@yahoo.com, jalamgoog2012@gmail.com
}

How to cite this paper: Rahman, M.S. and Alam, J. (2020) Solid Waste Management and Incineration Practice: A Study of Bangladesh. International Journal of Nonferrous Metallurgy, 9, 1-25.

https://doi.org/10.4236/ijnm.2020.91001

Received: November 30, 2019

Accepted: December 10, 2019

Published: January 30, 2020

Copyright $\odot 2020$ by author(s) and Scientific Research Publishing Inc. This work is licensed under the Creative Commons Attribution International License (CC BY 4.0).

http://creativecommons.org/licenses/by/4.0/

\begin{abstract}
Considering the geographical location and one of the very densely populated countries in the world, Bangladesh is very vulnerable to climate change and its adaptability. This paper has been designed with an attempt to inform the policy maker of Bangladesh regarding the potentiality of MSW as a renewable source of energy in Bangladesh. It deals with modern waste collection, management and incineration practices based on densely populated cities or towns like Bogura Municipality and Chattogram City Corporation. Waste to Energy (WtE) conversions not only reduce the land pressure problem in urban areas, but also generate electricity and heat to supply to the surrounding urban areas. The increase in generation of methane $\left(\mathrm{CH}_{4}\right)$ from municipal solid wastes (MSW) alarms the world to take suitable initiative for the sustainable management of MSW, as it is stronger than carbon dioxide $\left(\mathrm{CO}_{2}\right)$. By burning one mole of $\mathrm{CH}_{4}, 890 \mathrm{~kJ} \cdot \mathrm{mol}^{-1}$ heat is produced which is a major source of energy. This treatment technology is used in destruction of solid waste by controlled burning at high temperatures. With the release of heat, it can be accompanied and this heat from combustion can be converted into energy. This type of incineration is a high-quality treatment for Municipal or City Corporation solid waste like Bangladesh where were over crowded cities, towns and it can reduce the quantity and volume of a large amount of waste to landfill, which can recover energy and dispose in the compact zone. The results also examined that the total amount of solid waste produced in Bogura municipality is lower than that of Chattogram City Corporation. The percentage compositions of waste patterns are shown in both the Cities. The paper discusses these problems, analyses and finally, a recommendation has been proposed in order to understand the industrial situation enhanced.
\end{abstract}

\section{Keywords}

Population Distribution, Chattogram, Bogura Municipal or City Waste, Management, Waste to Energy, Incineration, Compact Zone 


\section{Introduction}

Bangladesh is facing severe impacts from climate change, including frequent flooding and salinity problems that are displacing a growing number of people from the country's huge Ganges river delta and furthering the move to urban areas. In 2018, Bangladesh was hit by heavy monsoon rains, which had an especially devasting impact on the thousands of Rohingya refugees at the Kutupalong refugee camp in Cox's Bazar. Kutupalong is reportedly the largest refugee camp in the world with more than 630,000 residents.

Wastes are substances or an object that no longer has a use or purpose, which are disposed of or are intended to be disposed of or required to be incinerated by the provisions of national law (Basel Convention). Bangladesh being a developing country with a population of over 170 million produces almost $2200-2400$ ton of waste materials per day per city. With the economic advancement and population growth, the generation of solid waste is also increased greatly in different areas of Bangladesh due to rapid industrialization. Solid waste management issue is the biggest challenge to the authorities of both small and large cities in developing countries. Improper solid waste management is one of the most serious local environmental problems in our country. Moreover, the projected value is to reach 2.2 billion tons per year by 2025 and 4.2 billion tons per year by 2050 [1]. Chattogram is one of the fastest growing cities just after Dhaka in Bangladesh that contributes about $15 \%$ of the total waste. Owing to the lack of motivation, awareness, proper selection of technology and adequate financial support, a considerable portion of wastes, $40 \%-60 \%$, are not properly stored or disposed in the designated places for ultimate disposal. All the MSW are disposed in the open dump sites after collecting from household or large waste containers in Dhaka and Chittagong City [2]. This study is also conducted with a line to assess the potentiality of WtE strategy for renewable electricity generation from MSW and associated fossil fuel carbon avoidance in Bangladesh. Two WtE technologies, such as mixed MSW incineration and LFG recovery, are selected for the assessment of renewable energy generation and carbon reduction, because these two options are the most preferable and mature technologies practicing around the world [3].

The waste can be solid or hazardous or nonhazardous but the authors have given special focus on solid waste. Materials are solid waste if they are deserted by being disposed of or burned or incinerated; or accumulated, stored, or treated (but not recycled) before or instead of being discarded by being disposed of, burned, or incinerated [4]. There are many cities in Bangladesh that produced a huge amount of these types of waste. Chittagong was established as a municipality in 1863 and was upgraded to City Corporation in mid-1990. It is the second largest City Corporation with an area of $168.07 \mathrm{sq} . \mathrm{km}$ and the biggest sea port as well. According to the 2001 census, about 55 percent of the population is male with literacy rate (more than 7 years old) of $65 \%$ according to the 2001 [5].

For the suitable analysis of major and minor patterns of research objective, we 
had chosen two cities in Northern and Southern portion of Bangladesh. Southern portion city is most important for major concern which is commercially important, with a large portion of garments business and solid waste generation amounted as large. Some of the common solid waste materials observed in these cities include paper, food waste, metals, plastics, glass or ceramics, vehicle parts and a small amount of e-waste. Most of these are known to be hazardous to the environment. Solid waste management refers to all activities pertaining to the control, collection, transportation, processing and disposal of those in accordance with the best principles of public health, economics, engineering, conservation, aesthetics and other environmental consideration [6]. It is reported by some researchers that individual waste generation rate (WGR) is very high in developed countries whilst total WGR is high in developing countries [7] [8]. Bangladesh is a developing Asian country (DAC) which is comprised of more than 522 urban hubs, generating collectively thousands of tons of MSW daily from various sources [9]. Many approaches are used for reducing the amount of waste in the area such as recycling; reuse, landfill etc. are to be considered. Factories which are well known for their production especially garment factories and steel re-rolling machines are more responsible for producing waste.

In different circumstances, Bogura is known as an entrance point and is also called the capital of North Bengal. On the basis of commerce and economics, it is an ancient first class Pauroshava in Bangladesh with 1000 light engineering factories established over the last four decades where employed nearly 50,000 workers and technicians [10]. Besides, Bogura municipality consists of 54 lac population and various industries producing various types of waste every day. Every day 20 wards of the city feed an enormous amount of waste that is collected in everyday. As the Bogura Municipality does not have any solid waste processing and treatment system at all, much of the environmental pollution is taking place in this region. Solid wastes are dumped on open areas through crude dumping and without any treatment. Thus, sanitary landfilling degrades the environmental quality [11]. Incineration is subjected of disposal of solid waste through high temperature $\left(980^{\circ} \mathrm{C}-2000^{\circ} \mathrm{C}\right)$ treatment process involving the combustion of organic materials.

Some researchers have made attention to solid waste management but very few studies focused on solid waste to convert into energy. We all have oil, plastic and garbage on our hands and; we are soliciting our feedback as to what the climate crisis agenda should include. Obviously, a bonafide climate crisis agenda can only happen in an honest and ethical geopolitical system sustaining the planet for the current and next generations. Bangladesh has severely faced power crisis for the last few years because of inadequate power generation capacity compared to demand. The projected total renewable energy potential (REP) from MSW is 4173.9 - 5645.3 GWh by 2030 and 6582.5 - 11,579.2 GWh by 2050 in Bangladesh. The truth is plain to see we live in a corrupt and criminal geopolitical system degrading, polluting and contaminating the planet for the grid and 
power. Many researchers have been given attention on solid waste management in Chattogram City Corporation while a little bit attention has been made in consideration in Bogura municipality. Our views are to show total scenario of industrial solid waste management and incineration practices in order to enhance the energy sector in Bangladesh.

\subsection{Present Scenario of Industrial Solid Waste in Bangladesh}

At this moment waste generation in Bangladesh is around 22.4 million tons per year. The total urban population is estimated to be as high as 78.44 million by 2025. There should have integration between greater amounts of waste generated and a higher urban population. The rate of waste generation is expected to increase to $220 \mathrm{~kg}$ per capita per year in 2025 [12]. Waste is simply collected, transported and dumped in landfill sites and the availability of new landfill sites is a challenge for the local bodies. A significant percentage of the population has zero access to proper waste disposal services, which will in effect lead to the problem of waste mismanagement. The total waste collection rate in major cities of Bangladesh such as Dhaka is only 37\% [13].

It is reported that when waste is not properly collected and it will be illegally disposed of and these will possess serious environmental health hazards for the nations of Bangladesh [14]. Both the cities especially Bogura municipality and Chattogram City Corporation need more attention from the Government for the collection, management and incineration practice of solid waste in order to improve environmental health hazard. If the scenario is not improved potentially; the people of the studied area are not at all hopeful to get a better environment let alone thinking about their livelihood. From the National scenario of solid waste generation of Bangladesh, it has been observed that we are far behind to procure and manage industrial solid waste properly. Almost six cities like Dhaka, Chattogram, Sylhet, Rajshahi, Khulna and Barishal WGR is $14,249.09$ tons per day. While in Bangladesh there are 328 Pauroshava of which 308 collectively accounts for solid waste generation is about 5954.33 tons per day [15] [16] as represented in Table 1.

While urban population growth and MSW increasing trend in Bangladesh is shown in Table 2, from which it is revealed that waste generation is increased linearly with the increase of year (1974-2025). If the situation is not improved significantly waste generation rate will be reached $47,064.00$ tons per day in 2025 which alarms for the next generation to be survived for their better livelihood [17] [18] [19].

In Bangladesh, there is no provision in storage of wastes at household and industrial waste while many households are not interested in disposing of garbage in nearby open spaces. It is, therefore, important to launch a long-term awareness building and campaigning program in the area so that people will be motivated about enhancing their own environmental conditions willingly. In each year, the average generated e-waste volume is 2.7 million metric tons globally; 
the devastating e-waste growth rate is $4 \%$ due to rapid technological breakthrough and short lifespan of electronic products [20]. Environmental protection is our prime concern for our existence and for the future generations as well. Though difficult, to maintain all relevant authorities need to take necessary steps for management, incineration and safe disposal as per the Bangladesh Environment Conservation Act, 1995 (Amendment, 2010) proper management is mandatory.

\subsection{Why Solid Waste Management and Incineration Are Essential}

Industrial solid wastes are mostly organic while E-waste and heavy metals are highly toxic and hazardous for the environment. It is our mission to reduce, reuse and recycle the materials for the sake of fulfilling SDGs of 3. Solid waste

Table 1. National scenarios of WGR in major cities of Bangladesh.

\begin{tabular}{|c|c|c|c|c|c|c|}
\hline \multirow{2}{*}{ Name of city } & \multirow{2}{*}{ No. of city } & \multirow{2}{*}{$\begin{array}{l}\text { Population } \\
\text { in } 2013 \\
\text { (million) }\end{array}$} & \multirow{2}{*}{$\begin{array}{c}\text { WGR } \\
\text { (kg/cap/day) }\end{array}$} & \multicolumn{2}{|c|}{ Total WGR (tons/day) } & \multirow{2}{*}{$\begin{array}{c}\text { Average WGR } \\
\text { (tons/day) }\end{array}$} \\
\hline & & & & Wet season & Dry season & \\
\hline Dhaka & 1 & 7.23 & 0.56 & 4047.62 & 5909.52 & 4978.57 \\
\hline Chittagong & 1 & 2.66 & 0.48 & 1275.11 & 1861.66 & 1568.38 \\
\hline Khulna & 1 & 0.67 & 0.27 & 181.74 & 265.33 & 223.53 \\
\hline Rajshahi & 1 & 0.46 & 0.44 & 200.76 & 293.11 & 246.94 \\
\hline Barisal & 1 & 0.35 & 0.25 & 86.49 & 126.28 & 106.39 \\
\hline Sylhet & 1 & 0.51 & 0.3 & 152.73 & 222.99 & 187.86 \\
\hline Municipalities & 308 & 19.36 & 0.25 & 4840.92 & 7067.74 & 5954.33 \\
\hline Other sub-cities & 208 & 5.75 & 0.15 & 863.14 & 1260.19 & 1061.67 \\
\hline Total & 523 & 36.99 & - & $11,584.63$ & $16,913.56$ & $14,249.09$ \\
\hline
\end{tabular}

Source: Menikpura, Sang-Arun, \& Bengtsson, 2013; Ahsan et al., 2014.

Table 2. Urban population growth and MSW increasing trend in Bangladesh.

\begin{tabular}{cccccc}
\hline Year & $\begin{array}{c}\text { Total urban } \\
\text { population (Million) }\end{array}$ & $\begin{array}{c}\text { Urban population } \\
\text { (\% total) }\end{array}$ & $\begin{array}{c}\text { Average annul } \\
\text { growth }(\%)\end{array}$ & $\begin{array}{c}\text { Total WGR } \\
\text { (ton/day) }\end{array}$ & $\begin{array}{c}\text { Average WGR } \\
\text { (kg/cap/ day) }\end{array}$ \\
\hline 1974 & 1.82 & 8.78 & 6.62 & - & - \\
1981 & 2.64 & 15.54 & 10.63 & 3013.70 & 0.49 \\
1991 & 20.87 & 20.15 & 5.43 & 9873.50 & 0.50 \\
2001 & 28.81 & 23.39 & 3.27 & $11,695.00$ & 0.50 \\
2004 & 32.76 & 25.08 & 4.29 & $16,382.00$ & 0.41 \\
2005 & 38.37 & 26.81 & 4.12 & $13,330.00$ & 0.48 \\
2010 & 46.04 & 30.46 & 3.62 & $16,382.00$ & 0.56 \\
2015 & 54.98 & 34.28 & 3.27 & $23,688.00$ & 0.57 \\
2017 & 58.75 & 35.70 & 6.0 & $27,654.00$ & 0.60 \\
2025 & 78.44 & 40.00 & - & $47,064.00$ & \\
\hline
\end{tabular}

Sources:; Waste concern, 2009, Ahsan et al., 2014; Abedin and Jahiruddin, 2015. 
management is a key concern for Bangladesh as by 2025 waste generation per capita will be $0.75 \mathrm{Kg}$ per capita per day and total amount of waste will be reached 21.07 million tons per day [21]. Waste needs to be managed in order to contact with humans or their immediate environment. Thus, main purpose of waste management is to isolate waste from humans and the environment. Collected municipal solid waste must be treated in order to reduce the total volume and weight of material that requires final disposal. Treatment changes the form of the waste and makes it easier to handle. It can also serve to recover certain materials, as well as heat energy, for recycling or reuse. In ancient cities, wastes were thrown onto unpaved streets and roadways, where they were left to mount up. It was not until 320 bce in Athens that the first known law forbidding this practice was established. At that time a system for waste removal began to evolve in Greece and in the Greek-dominated cities of the eastern Mediterranean. Many wastes are mixtures of hazardous and non-hazardous wastes along with high cost solid materials. There are many methods of solid waste disposal and management that are open burning includes; dumping into the sea, sanitary landfills, incineration, composting, ploughing in fields, hog feeding, grinding and discharging into sewers. As the technology is changing on day to day basis, it is our bounden duty to establish high quality MSW management system and all these organic solid wastes are converted into energy with a view to protect the environment and to make a healthy nation.

Improper disposal of municipal solid waste can create unsanitary conditions, and these conditions in turn can go in front to pollution of the environment and to outbreaks of vector-borne diseases that are spread by rodents and insects. A technological approach to solid-waste management began to develop in the latter part of the $19^{\text {th }}$ century. Impermeable garbage cans were first introduced in the United States, and sturdier vehicles were used to collect and transport wastes. A significant development in solid-waste treatment and disposal practices was marked by the construction of the first refuse incinerator in England in 1874. From the very outset of the $20^{\text {th }}$ century, $15 \%$ of major American cities were incinerating solid waste. However, most of the largest cities were still using primitive disposal methods such as open dumping on land or in water [22]. By segregating key toxic constituents, isolating solid, liquid fraction, keeping hazardous streams away from non-hazardous wastes, generator must be saved substantial amounts of money on disposal or find new opportunities for recycling and reuse of wastes. In Bangladesh, the generation of wastes for different industries has not been detailed, which is necessary for wastes exchange system or for adopting treatment alternatives for different wastes. One of the important by-products of this decomposition is methane gas which is poisonous and explosive when diluted in the air, and it can flow long distances through porous layers of soil. If it is allowed to collect in basements or other confined areas, life threatened dangerous conditions may arise. In modern landfills, methane movement is controlled by impermeable barriers and by gas-venting systems. In some landfills the methane gas is collected and recovered for use as a fuel. After being 
isolated solid waste and by combusting them; carbon dioxide, carbon monooxide, heat and energy have been formed and by reduction of; carbon dioxide or carbon monooxide converted into methane. The methane is more potential greenhouse gas (GHGs) than carbon dioxide and by breaking or cracking down of it, carbon dioxide will be formed in fact that to increase greenhouse gases which accounts for $51 \%$ while methane is $17 \%$ for increasing global temperature [23]. Continuous surveillance of the site and its surroundings must be maintained to check that the disposal of hazardous wastes can continue without posing a threat to the environment and to the general public. In many countries, land is a readily available commodity and often areas of non-productive or derelict land might be used for waste disposal. However, land can be utilized in the near vicinity or on the premises of industrial companies, thereby reducing transportation costs. The potential also exists tore claim certain areas for recreational purposes. Landfilling is still the major disposal method in many countries. Many landfills belong to a landfills gas extraction technique installed after closure to extract the landfill gas generated by decomposing waste materials. Gas is being pumped out of the landfills using perforated pipes and burned in a gas engine to generate electricity. All non-hazardous solid waste from a community that requires collection and transport to a processing or disposal site is called refuse or municipal solid waste (MSW). Refuse includes garbage and rubbish whereas garbage is mostly decomposable food waste; rubbish is mostly dry material such as glass, paper, and cloth, wood. Garbage is highly decomposable, whereas rubbish is not. Trash is rubbish that includes bulky items such as old refrigerators, couches, or large tree stumps which requires special collection and handling. Solid waste may also provide breeding sites for mosquitoes. Mosquitoes of the Aedes genus lay eggs in water stored in discarded items such as tins and drums; these are responsible for the spread of dengue and yellow fevers. Such conditions may also attract mosquitoes of the Anopheles genus, which transmit malaria. Poor management of the collection and disposal of solid waste may lead to leachate pollution of groundwater. This might be caused by significant problems if the waste contained toxic materials. The effect of living in an unhygienic and untidy environment may lead people to become demoralized and less motivated to improve conditions around them [24].

For the attainment of sustainable growth with minimal environmental cost the world comes up with new idea of "Green Growth" where economic growth and conservation of environment through pollution control could be achieved simultaneously. To fulfill the SDGs, all concerned people of Bangladesh should look forward in front line in order to safe, secure and greener livelihood and to make healthy nations as well.

\section{Methodology}

The studied areas were covered with Bogura municipality (Figure 1) and Chattogram City Corporation (Figure 2) which comprises 41 wards and two parts divided by Karnafuly River where one part is a densely populated residential 
area and the other one is a heavily industrial area. The population density of municipal area of the city is also very high and about 20,000 to 30,000 per sq $\mathrm{km}$. Its population is almost 3 million among which $55.00 \%$ male and $45.00 \%$ female [25]. The objective of the studies is recyclable and reusable solid waste pattern. Furthermore, it has been focused on the present status of solid waste and its respective management as well as incineration practices. It was conducted by using several municipal inorganic wastes and the related factors of this study are different types of solid waste collection, transportation, and storage; and incineration system in selected area. These studies also identify the collection of wastes and incineration accompanied with the authority, future management plan with the consciousness of municipal residents about waste management.

\subsection{Survey on Field}

The field survey of this study has been performed in Bogura Municipality and Chattogram City Corporation. The dumping sites of Bogura Municipality and Chattogram City Corporation are demonstrated in Figure 3 and Figure 4 respectively.

Mixed methods were applied to collect information, analyzing and integrating qualitative and quantitative data. Primary data were collected through predesigned questionnaire from the 200 respondents such as hawker, day labor, rickshaw, van puller, business man, and employees of both government and non-government organization to assess the exact scenario of solid waste management with direct field observation. Focus group discussion (FGD) was conducted with the stakeholders and secondary data were also collected through proper documentation of internet, journals, books, research articles and periodicals. In terms of primary data collection; we have to divide our research area into two parts. Conversely, Bogura municipality consists of 21 wards of which 8 majors of them were selected as those eight were densely populated residential and industrial areas. The study finds out the effect of common people on solid waste management system, incineration practices of Bangladesh. A schematic diagram for the sources of data collection and analysis is shown in (Figure 5).

\subsection{Official Survey}

These types of data collection were secondary and were about population, volume of waste generation, activities exiting on solid waste management in selected study area were collected. It was collected from Bogura municipal office and Chattogram City Corporation office, internet and books. For assessing expert opinion, the key informant interview (KII) was conducted with the various stakeholders who were experts and associated with solid waste management (SWM) practice in the selected area. The engineers of Municipality and City Corporation along with the planner are given an opinion about present solid waste management with their upgrading process for better solid waste management and incineration practices. 


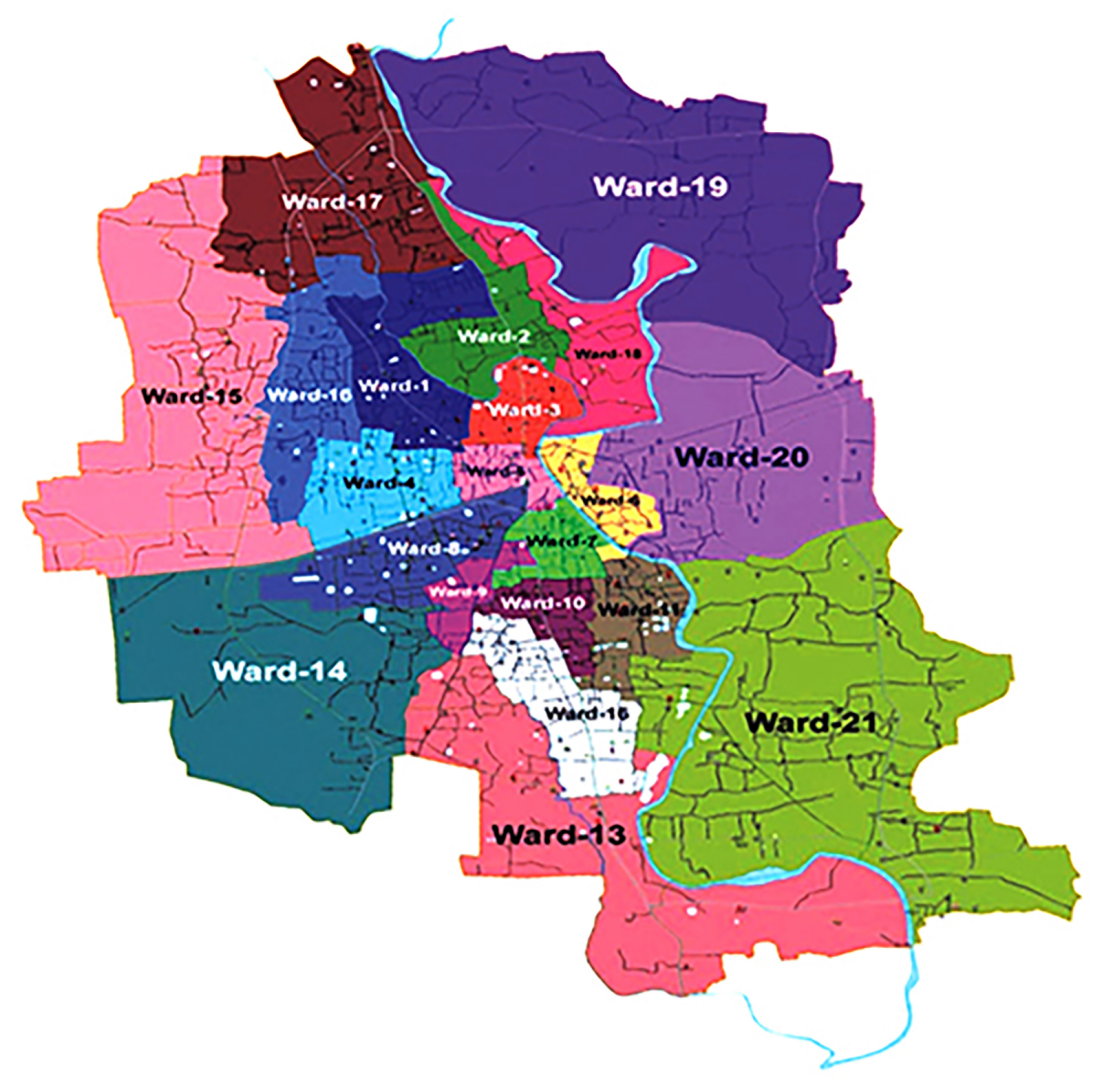

Figure 1. Map of Bogura Pauroshova.

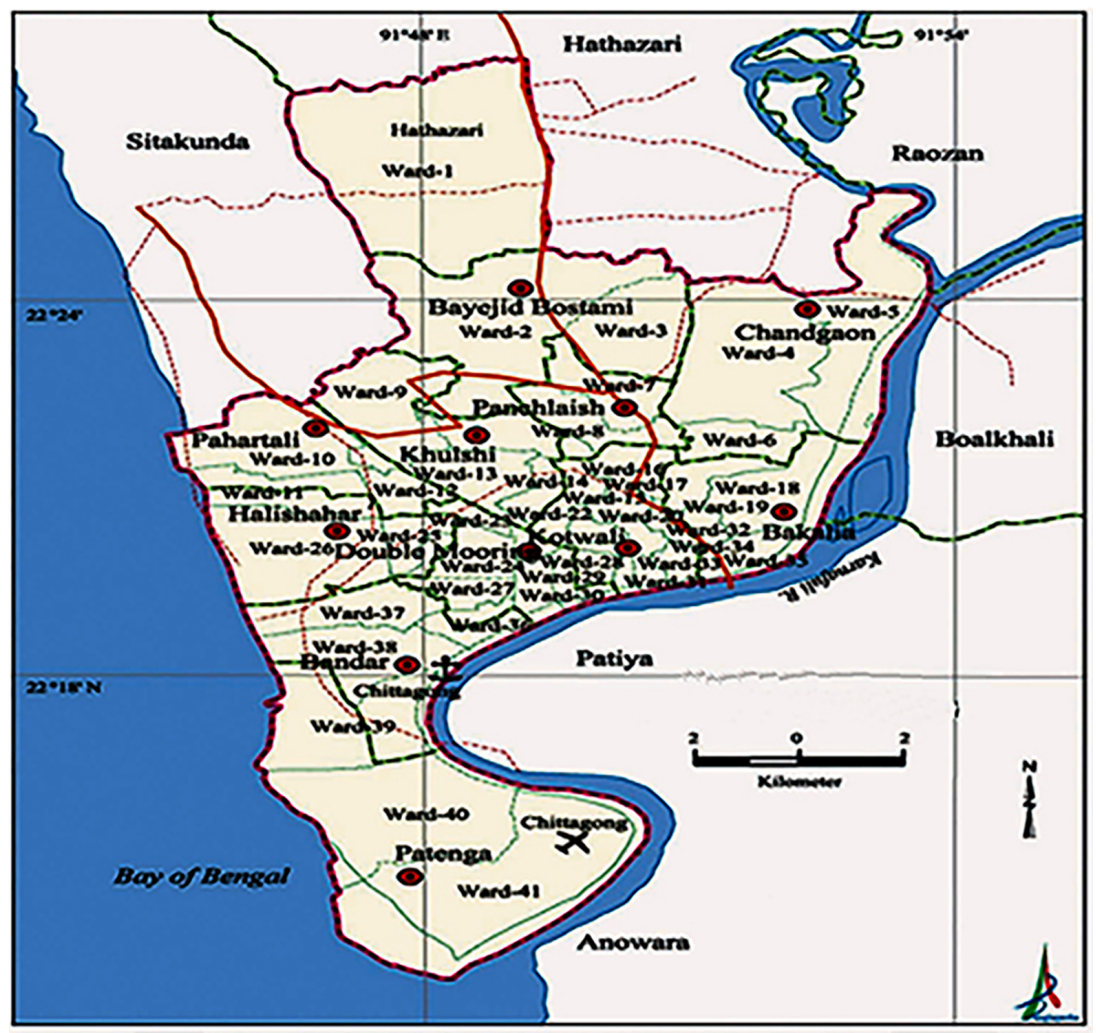

Figure 2. Map of Chattogram City corporation. 


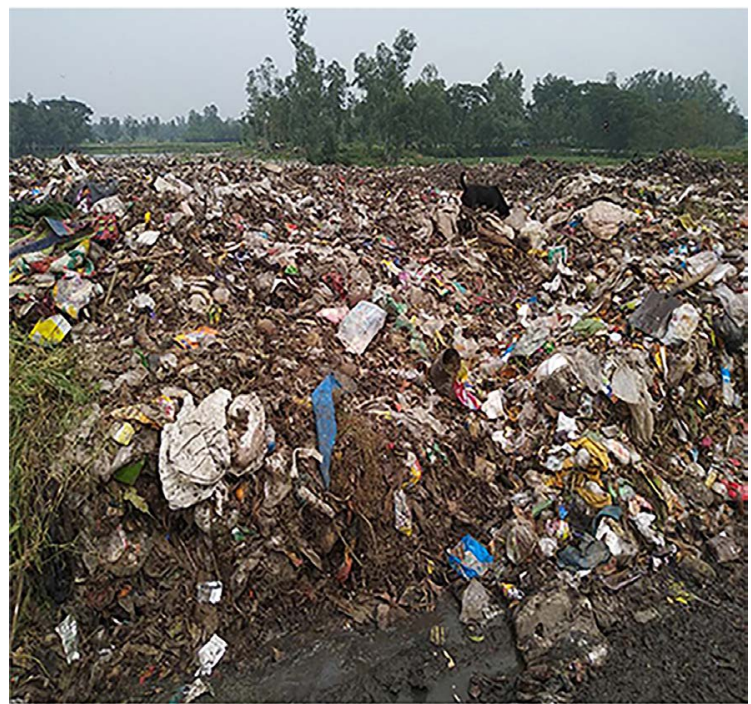

Figure 3. Solid waste in Bogura municipality.

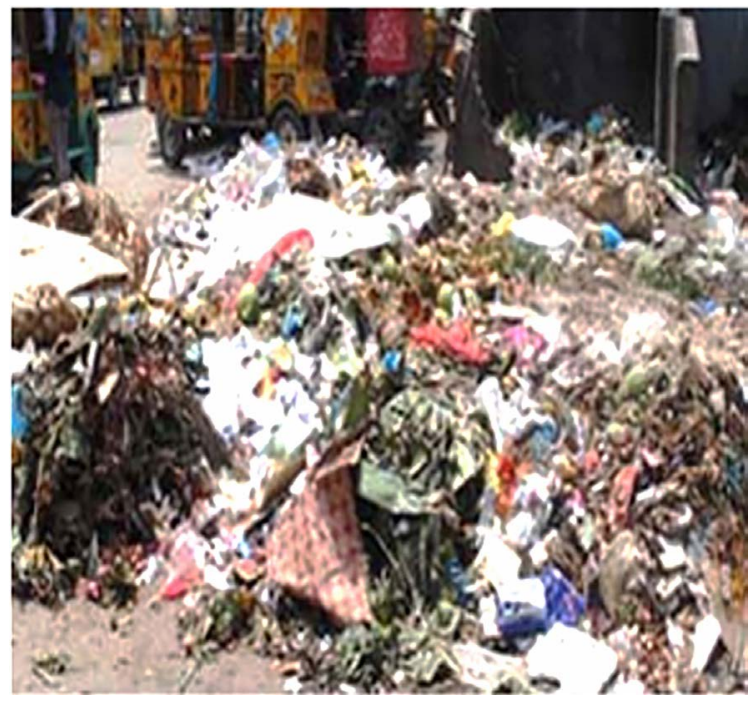

Figure 4. Solid waste in Chattogram City corporation.

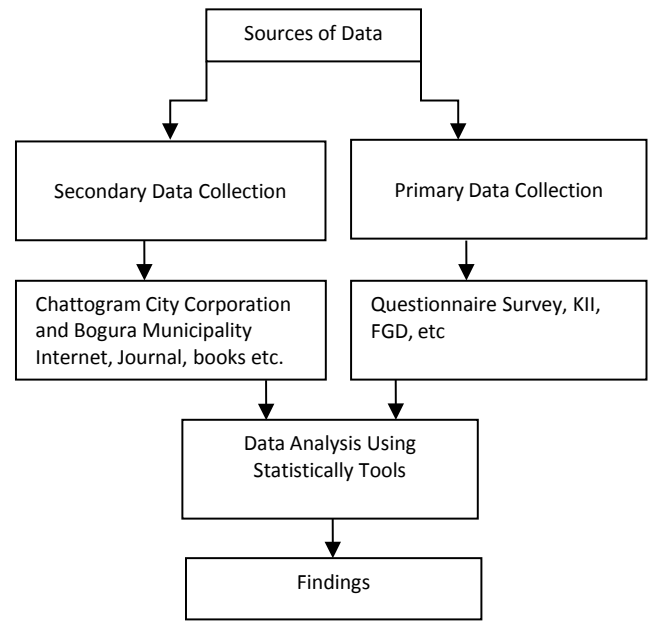

Figure 5. Sources of data collection and analysis. 


\subsection{Data Collection}

The study was conducted from February 2017 to August 2017 for seven months. Successively we had visited Bogura municipality of major wards no 2, 3, 4, 7, 8, $10,11,13$ and 17; and collected materials of various types of waste separated to be estimated which are shown in Table 3. Similarly, we had also collected wastes of Chattogram City Corporation from major wards no 11, 21, 22, 27, 28, 29, 30, 38, 40 and 41. Collected wastes are separated, analyzed as described in Table 4.

Table 3. Waste amount in Bogura municipality.

\begin{tabular}{lcc}
\hline Waste & Products & Amount (Kg/capita/day) \\
\hline & Paper & 0.147 \\
1) Residential & E-waste & 0.088 \\
& Metals & 0.012 \\
& Vehicle parts & 0.018 \\
& Domestic things & 0.012 \\
& Textile & 0.019 \\
\hline & Cement & 0.014 \\
& Paints & 0.011 \\
& Pesticides & 0.001 \\
& Petroleum & 0.019 \\
& Medicines & 0.018 \\
\hline & & 0.013 \\
\hline
\end{tabular}

Table 4. Waste amount in Chattogram City corporation.

\begin{tabular}{|c|c|c|}
\hline Waste & Products & Amount (Kg/capita/day) \\
\hline \multirow{6}{*}{ 1) Residential } & Paper & 0.142 \\
\hline & Plastic & 0.091 \\
\hline & E-waste & 0.011 \\
\hline & Metals & 0.008 \\
\hline & Vehicle parts & 0.010 \\
\hline & Domestic things & 0.019 \\
\hline \multirow{6}{*}{ 2) Industrials } & Textile & 0.024 \\
\hline & Cement & 0.012 \\
\hline & Paints & 0.015 \\
\hline & Pesticides & 0.017 \\
\hline & Petroleum & 0.018 \\
\hline & Medicines & 0.023 \\
\hline \multicolumn{2}{|c|}{ Total Collection } & 0.413 \\
\hline
\end{tabular}




\subsection{Data Analysis, Results and Discussion}

Depending on areas; waste patterns were different and found two types, which are industrial waste and residential waste. Quantification and percentage of different solid wastes were calculated from $5 \mathrm{~kg}$ sample. The results examined that total amount of solid waste produced in Bogura municipality is about 200.88 tons per day and Chattogram City Corporation is 1233.79 tons per day. Standard molecular composition of different solid wastes category based on dry weight fraction of solid waste was used in this study. It has been reported that for safe and secure management of e-waste is becoming a foremost crisis on account of the presence of toxic substances [26] [27]. The Chattogram City Corporation produces over 2220 tons of wastes daily. It is responsible for waste management program and it took up a pilot project for garbage treatment plant in 2004. The project at the Chattogram City Corporation garbage dumping ground at Halishahar had gone into operation to produce fuel from rubbish. The major sources of MSW are household, industry, fresh market, shopping mall, restaurant and slaughterhouse [28]. It was found that the waste consists of several components mostly plastic, paper, metal, e-waste, vehicle parts in residential areas. Rubbish, garbage, trash, junk, slags, fly ash, solvent acidic water etc. The organic materials start to undertake biochemical reactions in presence of air near the surface of the landfills. One of the reports proven that the average molecular structure of organic compound can be approximated by the molecular composition MSW is $\mathrm{C}_{6} \mathrm{H}_{10} \mathrm{O}_{6}$ [29] [30]. The major biochemical reaction in landfills is anaerobic digestions which takes place in three stages: firstly, through fermentation process bacteria hydrolyze to form organic molecule complex into soluble molecules where zymase enzyme is used. Secondly, the produced ethanol is converted into ethanoic acid and eventually, the methane is formed by decarboxylation reaction or by the hydrogen reduction process of carbon dioxide. As with $\mathrm{CO}_{2}$, human activity is increasing the $\mathrm{CH}_{4}$ concentration quicker than it can be offset by natural sinks. Anthropogenic sources currently account for approximately $70 \%$ of total annual emissions, leading to substantial increases in concentration over time. $\mathrm{CO}_{2}$ can be converted into $\mathrm{CO}$ by reducing agent or $\mathrm{H}_{2}$ reduction process likely the source of heat and energy as well. It is done by cost-effective way, scientists used an entirely new form of catalyst, instead of noble metal nano particles, and they used single atoms of nickel. The regulation of carbon dioxide emissions will apply to all fossil fuel energy sources; however, previous actions by the Environmental Protection Agency have tailored the regulations in a way that fuel sources such as natural gas readily comply while coal-powered plants require substantial investments to remain operational. The following reactions represented as follows [31]:

$$
\begin{gathered}
\mathrm{C}_{6} \mathrm{H}_{12} \mathrm{O}_{6} \rightarrow 2 \mathrm{C}_{2} \mathrm{H}_{5} \mathrm{OH}+2 \mathrm{CO}_{2} \\
\mathrm{CH}_{3} \mathrm{COOH} \rightarrow \mathrm{CH}_{4}+\mathrm{CO}_{2} \\
\mathrm{CO}_{2}+4 \mathrm{H}_{2} \rightarrow \mathrm{CH}_{4}+2 \mathrm{H}_{2} \mathrm{O}
\end{gathered}
$$


Equation (I) represents the ethanol production from starch, after oxidizing $\mathrm{C}_{2} \mathrm{H}_{5} \mathrm{OH}$ by chromic acid $\mathrm{CH}_{3} \mathrm{COOH}$ is formed Equation (II), the route for the production of $\mathrm{CH}_{4}$ by decarboxylation process and Equation (III) represent the production of $\mathrm{CH}_{4}$ from $\mathrm{CO}_{2}$ through the reduction of $\mathrm{H}_{2}$. The maximum amount of natural gas can be generated during anaerobic decomposition or digestion (AD). Although, the heat production in this reaction is low and highly plausible to convert almost 50\% - 70\% methane and 30\% - 50\% carbon dioxide and others minute amount of impurities associated such as $\mathrm{NH}_{3}, \mathrm{H}_{2} \mathrm{~S}$ [32] [33].

On the contrary, in our everyday practice, we are throwing huge amounts of starch like food from which the key component of natural gas $\left(\mathrm{CH}_{4}\right)$ would be produced with proper conditions and reactor design. The citizens of Bogura region are deprived of various waste management facilities since wastes are dumped everywhere besides, highway road, in front of the market, home or any road sites. People of this region are also feeling odors of sited garbage and being distressed for their healthy life. Citizens are stated their view as per importances of the city Bogura is not well developed irrespective of roads, markets and waste management system. In Bogura it was found that wastes are dumped largely beside the high way in front of Pundra University, Gokul; the bad odor of it is not only hazardous for the passerby but also for the mass people which degrades the quality of environment and eco-system as well. Different types of residential and industrial wastes pattern of Bogura municipality and Chattogram City Corporation; and sources are illustrated in Table 5 and Table 6 respectively.

Table 5. Residential wastes.

\begin{tabular}{ll}
\hline Product & Wastes \\
\hline 1) Paper & $\begin{array}{l}\text { Paper scraps, cardboard, newspapers, magazines, bags, boxes, } \\
\text { wrapping paper, telephone books, shredded paper, and paper } \\
\text { beverage cups }\end{array}$ \\
2) Plastic & Bottles, packaging, containers, bags, lids, cups. \\
3) E-waste & Broken TV, radio, computer, wires. mobile accessories \\
4) Metal & Tins, non-hazardous aerosol cans, appliances (white goods), \\
5) Vehicle parts & Bicycles, Automobile parts, shipping unusable parts.
\end{tabular}

Table 6. Industrial wastes.

\begin{tabular}{ll}
\hline Products & Wastes \\
\hline 1)Textile & Dyes, heavy metals, organic chlorine compounds, solvents. \\
2)Cement & Slag, fly ash, chemical ingredients \\
3)Paints & Heavy weight particles, solvents, pigments, organic residues. \\
4) Pesticides & Organic chlorine compounds, organic phosphate compounds \\
5)Petroleum & Oil, phenol, organic compounds \\
6) Medicines & Organic solvents and residues, heavy metal $(\mathrm{Hg}, \mathrm{Zn}, \mathrm{Pb}, \mathrm{Cr})$ \\
\hline
\end{tabular}


Even though, Bogura is a first-class Pauroshava but most of the people of this region are deprived of all healthcare benefits. Especially during the rainy season, the situation becomes unwanted, unhealthier and severely life threatened due to the throwing of wastes on the main road sites or everywhere else. It is assumed that last a decade, there was no significant development in the road owing to the fact that traffic jam is daily events of this Pauroshava which is the concern of mass people. While in Chattogram City Corporation, and during the rainy season the dumping wastes mixed with water and affect the quality of healthier life of the citizen. The people of both the cities are unanimously confirmed that the management storage and discharging system of solid waste are much better in Chattogram City Corporation than the Bogura municipality. Many of the people should be taken under consideration for the awareness of waste management by showing the hazardous effect of wastes. Besides, when waste materials are thrown in front of the houses or roads; passerby feels untidy, unhygienic and unhealthier life.

Focus group discussions (FGD) were performed in 6 individuals group of people of both the cities. During the focus group discussion, the participants shared mixed views regarding their expectations of the service implementation of solid waste collection and management systems. Some of them are giving their opinion that the lack of trained and skilled manpower is problematic which is arising day by day. Many of them are raising their voice regarding financial crisis and awareness is the prime factor for implementing industrial solid waste procurement. A little bit of them shares that the people of the studied area are carrying diseases owing to the fact that whenever in touch with waste materials. Some respondents express views that they did not have enough knowledge regarding the reuse or recycle of waste materials.

For the key informant interviews (KII) it was conducted with the various stakeholders who were efficient and associated with solid waste management (SWM) of both the cities. They are strongly agreed that the current conditions of solid waste management are not only poor but also affect the healthier life of the citizen. Besides, awareness towards people must be taken in consideration through various programs like TV channel or media. Some experts have given their views to provide interest free loan for setting up well designed reactor for their industry to avoid carbon emission. There are different kinds of land usurpers in Bangladesh who usurp land illegally by throwing garbage and then use it for their own needs as well as demand the usurped land as their own property and in this way; they are creating dumping sites anywhere else.

\subsection{Composition of Solid Waste}

Solid waste refers here to all non-liquid wastes. In general, this does not include excreta, although sometimes nappies and the feces of young children may be mixed with solid waste. Solid waste can create significant health problems and a very unpleasant living environment if not disposed of safely and suitably. If not 
correctly disposed of, waste may provide breeding sites for insect-vectors, pests, snakes and vermin (rats) that increase the livelihood of disease transmission. The major components of municipal waste including; paper, plastic, metals, can, cement, bricks, boards, textile, vehicle parts, E-waste, petroleum, and ashes, chemical composition found in the solid wastes showed high moisture content, high ash and inorganic contents and comparatively low nitrogen, phosphorus and potassium. Solid waste collection, management and incineration practice is the biggest challenge to the authorities of both small and large cities' in developing countries. This is mainly due to the increasing generation of such solid waste and the burden posed on the municipal budget. Physical residential wastes pattern and industrial waste are typically different while there has some similarity due to the current industrial establishment pattern. The typical physical compositions of waste of Bogura municipality and Chattrogram City Corporation are illustrated in Figure 6 and Figure 7 respectively. It is estimated that the percentage compositions of Bogura municipality consist of waste materials like papers $40 \%$, plastics $24 \%$, textiles and domestic things are $4 \%$, while metals, petroleum and pesticides are almost $5 \%$ but cements, vehicle parts, medicines and E-waste forms about $3 \%$. On the other hand, the percentage compositions of Chattrogram City Corporation having found papers $36 \%$, plastics $23 \%$, petroleum $5 \%$, paints and pesticides $4 \%$, textile $6 \%$, domestic things $5 \%$, while cement, vehicle parts and E-waste 3\%, medicine 6\%. In Chattogram City Corporation belongs higher percentage of textile, paints, vehicle parts compare to Bogura municipality. The average physical components of MSW is $67.7 \%$ vegetable and food waste (VFW), $9.7 \%$ papers, $5.1 \%$ plastic/leather/rubber, $0.3 \%$ metals, $1.2 \%$ glass/ceramic, $4.2 \%$ wood/grass/leaves, $2.5 \%$ rags/textile/jute, $0.7 \%$ medicine/chemical and $8.6 \%$ others in Bangladesh. The component of MSW was $77.3 \%-78.9 \%$ VFW, $4.5 \%$ - 9.5\% papers, $2.8 \%$ - 3.6\% plastic/leather/rubber, $1.1 \%-1.3 \%$ textile/woods, $0.7 \%-1.1 \%$ metals, $0.5 \%-2.3 \%$ glass/ceramics, $9.6 \%$ garden waste and $4.3 \%-5.2 \%$ others in Khulna City [34] [35].

The principal component of MSW in Chattogram City was 62\% - 72\% VFW and the VFW generation increased from $47 \%$ - 53\% for higher socioeconomic group to $88 \%-89 \%$ for lower socioeconomic group [36] [37].

Hence it is high time to rethink and to be aware regarding resolving the strategic plan of industrial solid waste management and its reuse. Apart from this, the household solid wastes (HSW) contribute about $90 \%$ of the total MSW streams and around $80 \%-92 \%$ of which is organic solid waste (OSW) shown by [38].

\section{Incineration Practice}

Incineration is a disposal method in which solid organic wastage is subjected to combustion so that to convert it into residue and gaseous product. Waste incineration is the combustion of solid waste in controlled incineration facilities. Modern refuse combustors have tall stacks and specially designed combustion 


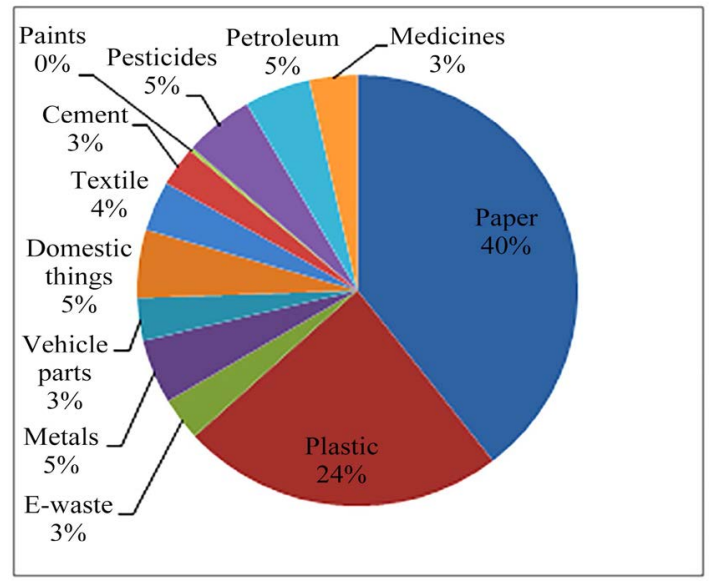

Figure 6. Typical pattern of solid waste in Bogura municipality.

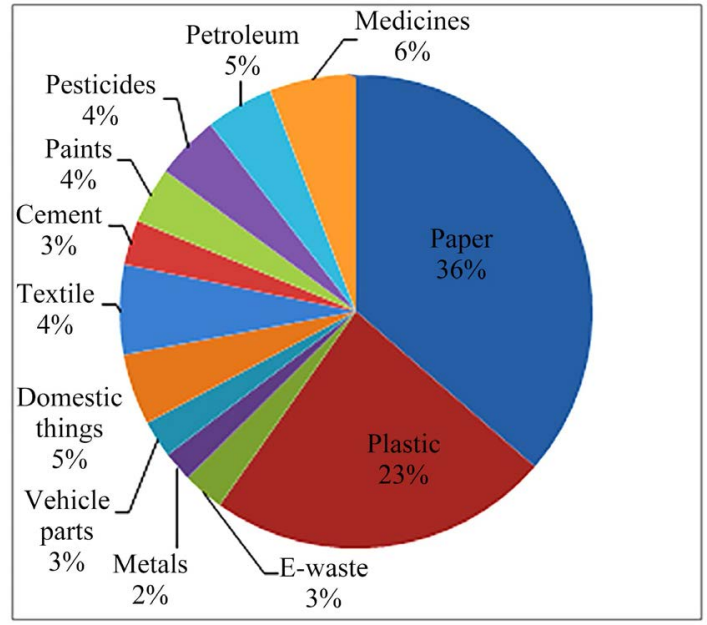

Figure 7. Typical pattern of solid waste in Chattogram City corporation.

chambers, which provide high combustion temperatures, long residence times, and efficient waste agitation while introducing air for more complete combustion. Incineration has been used widely for waste disposal, including household, hazardous, and medical waste but there is increasing public concern over the benefits of combusting the waste versus the health risk from pollutants emitted during combustion. At mass burn incinerators, also known as mass burn combustors, the heat generated from the burning material is turned into useable electricity. The byproducts are ash, which is landfilled, and combustion gases. Incinerators are burning municipal solid waste produce the pollutants carbon monoxide, sulfur dioxide, and particulates containing heavy metals. The generation of pollutants can be controlled by proper treatment and the proper use of air emission control devices, including dry scrubbers, electrostatic precipitators, fabric filters, and proper stack height. Waste disposal, many believe, requires an integrated approach that includes reduction, recycling, composting, and landfilling, along with incineration. It has become the method of choice of many waste management companies and municipalities [39]. It can be very useful because it 
decreases quantity, filters trapping pollutants, provides control over odor and noise, prevent the production of methane and ultimately reduces pollution. During combusting process energy content of solid waste highly influences the waste combustion processes in an incinerator to generate the electricity. For the generation of electricity by combusting solid waste, un-segregated wastes are feed stock combusted in a furnace or boiler, under high temperature $\left(980^{\circ} \mathrm{C}\right.$ to $1090^{\circ} \mathrm{C}$ ) conditions with excess oxygen. Solid waste feed stock is converted into heat, flue gases and particulates, and incinerator bottom ash. Incineration can reduce about $90 \%$ MSW volume, prevent pollution, improve recycling rates and decrease the dependence on fossil fuels [40]. The heat is used to produce steam and based on the Rankine cycle principle in steam turbine electricity is generated. Under an ideal situation, solid waste combustion processes chemical reaction is represented as the following equation [41].

$$
\begin{aligned}
& \text { Organic matter }\left(\mathrm{C}_{\text {org }}\right)+\text { Excess air }\left(\text { Mainly } \mathrm{O}_{2}\right) \\
& \leftrightarrow \mathrm{CO}_{2}+\mathrm{H}_{2} \mathrm{O}+\mathrm{O}_{2}+\mathrm{N}_{2}+\text { Ash }+ \text { Heat. }
\end{aligned}
$$

Energy recovery from waste is the conversion of non-recyclable waste materials into useable heat electricity or fuel through a variety of processes including combustion, gasification anaerobic digestion and landfill gas recovery (LFG) which is often called waste to energy (WtE). There is an argument that incinerators destroy valuable resources and it might reduce incentive for recycling. The question however arises that countries like Europe that are recycling the most (up to 70\%) also incinerate their residual waste to avoid landfilling.

Bangladesh, with its low-lying coastal position and large, dense population that is projected to grow to 202 million by 2050 , has been especially vulnerable. The government of Bangladesh seeks to achieve 100 percent coverage by 2021. This target is well in advance of SDG 7, which aspires to 100 percent electricity access by 2030. Bangladesh is an example of a country with rapid energy demand growth. Its primary energy consumption has grown at a rate of 6.4 percent over the 2007-2017 periods. In 2018, while GDP rose by 7.9 percent, primary energy consumption increased by 8.6 percent over 2017. The German Watch Climate Risk Index ranked Bangladesh sixth on its list of countries affected by climate change during 1997-2016 with 187 severe climate events inflicting estimated losses of $\$ 2.3$ billion [42]. Another researcher shows that the modern WtE plants facilitate to recover energy and metals cut down GHGs emissions [43].

However, the produced ashes can be implemented in various civil engineering works and the strategy of utilizing MSW for the generation of electricity is socially more cost-effective and sustainable [44].

The drying stage is significant as municipal waste typically contains $30 \%$ water. The materials which are introduced to the bed must be dried before it can be burned. The water content is the main factor, influencing the calorific value of the waste. As the waste heats up, it loses volatiles which burn on top of the bed and when ignition temperature is reached in the bed through oxygen; emitting carbon dioxide and gradually pyrolyzing into char. Once the oxygen is used up, 
the carbon dioxide is reduced to carbon monoxide, which burns in the freeboard along with pyrolysis products. Eventually, the char burns to ash which drops into the ash pit. Usually, the ash contains less than 5\% carbon, and certainly the permitted carbon in ash may be controlled by legislation. Once more it is emphasized that all these bed combustion processes take place when the bed is being mixed; at present, there is no good mathematical model of the total process and empirical correlations are used for bed design. Municipal solid-waste incinerators are designed to receive and burn a continuous supply of refuse. A deep refuse storage pit, or tipping area, provides enough space for about one day of waste storage. The refuse is lifted from the pit by a crane equipped with a bucket or grapple device. It is then deposited into a hopper and chute above the furnace and released onto a charging grate or stoker. By shaking the grate, particulates are shieved out from the waste and moved through the furnace using air circulation for proper incineration. Modern incinerators are usually built with a rectangular furnace, although rotary kiln furnaces and vertical circular furnaces are available. Furnaces are constructed of refractory bricks that can withstand the high combustion temperatures. Combustion in a furnace occurs in two stages: primary and secondary. In primary combustion, moisture is driven off, and the waste is ignited and volatilized. In secondary combustion, the remaining unburned gases and particulates are oxidized, eliminating odors and reducing the amount of fly ash in the exhaust. Waste-to-energy plants operate as either mass burn or refuse-derived fuel systems. A mass burn system uses all the refuse, without prior treatment or preparation. A refuse-derived fuel system separates combustible wastes from non-combustibles such as glass and metal before burning. If a turbine is installed at the plant, both steam and electricity can be produced in a process called cogeneration. Separating, recovering, and reusing components of solid waste that may still have economic value is called recycling.

It is a fact that incinerators provide a pivotal role for humanizing energy efficiency. It is a major point that energy in the form of electricity is likely to introduce about eight times more than the same amount of energy as steam heat. Hence, it is important that the proportion of waste converted to electricity is maximized in the power grid of Bangladesh.

\section{Limitations of the Study}

During the studies, it was observed that very few researches have been done on Bogura municipality though it is the oldest commercially important district in North Bengal and Bangladesh as well. On the other hand, Chattogram City Corporation once was called the cleanest City of Bangladesh due to overwhelming presence of green trees in the hilly areas which is also the most important commercial center for the sake of its accessibility by both air and sea from all parts of the world but with the passage of time it is massively changed because of huge industrialization and population growth. Solid waste treatment is essential in view of saving environment and to make greener Bangladesh. Due to the lack 
of resources for collecting, processing and awareness of waste materials of stakeholder are dumped everywhere else. Some of the stakeholders of both cities are strongly concerned about management by incineration practices; due to the lack of finance or poor monitoring system of industries they are not well aware of implementing solid waste management properly. Some people are afraid of giving appropriate information which is another debatable issue of this research. The people who are associated with filling questionnaire survey, not well enough educated, thus noncooperation have been seized for suitable documentation. According to technical team of these two major and minor cities, they want to utilize those wastes to convert energy which is much more advantageous in industrial operation and nations as well. During the field survey, it is revealed that lack of integrated planning, physical and technical limitations, coordination and communication among the city dwellers, private organizations, government authority and the city authority, the attempts have not been succeeded to improve the solid waste management and processing as well.

\section{Conclusion}

Bangladesh especially in densely populated city areas, the amount of solid waste is increasing day by day owing to the industrialization. With the increasing population exponentially, it is even more important to be considered about how well individuals take care of the planet. We should not forget that our land is limited, resources are also limited, and the health of the plant can only be hurt to a limited extent. Biodegradation of MSW is an important factor that governs the amount of recyclable material particularly the organic wastes. It was revealed that the estimated value of the total solid waste all over the country in major cities of Bangladesh is 14,249.09 tons per day of which Dhaka City Corporation alone is accountable for about $37 \%$. The results showed that the total amount of solid waste produced in Bogura municipality was about 200.88 tons per day and Chattogram City Corporation is 1233.79 tons per day. Besides, it is found that the percentage compositions of solid waste of both the investigated areas are very close to each other irrespective of material contents. The physical components of both the investigated area were shown in irrespective of percentage compositions. Compost plant might be economically beneficial to setup in some municipalities with the technical and financial support of NGOs or donor agencies. In Chattogram City Corporation belongs higher percentage of textile, paints and vehicle parts compared to Bogura municipality. During the anaerobic digestion (AD) of Municipal Solid Waste (OFMSW), $\mathrm{CH}_{4}$ is produced through the chemical reactions of $\mathrm{CO}_{2} \& \mathrm{H}_{2}$. Coal still dominates power generation, as over $40 \%$ of the power produced in the United States comes from this fuel source. It is thus, possible to convert energy by burning solid waste under suitable conditions and to enhance the power grid of Bangladesh. Most of the people in the Bogura Municipality and Chattogram City Corporation believed that the municipal waste collection with management system is extremely underprivileged 
and weak than the necessity while better than the Bogura municipality. Lack of published data on Bogura Municipality solid waste generation is in increasing trend with the growth of urban population. Solid waste management system of both the investigated area should be increased for healthier life and incineration practices with high temperature in compact zone along with suitable conditions that help to enhance the power grid. Therefore, it is our bounden duties for proper management and incineration practices of industrial solid waste in order to make the environment friendly and to ensure SDGs and lower emission of GHGs which is only possible by taking initiative globally. By managing industrial solid waste in scientific way nation may get rid of severe life-threatening diseases like Dengue, Malaria, Chikungunia, Yellow fever, Zika virus etc. The research will be helpful for policy maker, planner, implementer and other stakeholders towards adopting more effective strategy for management. It is evident that possible treatments are required before discharge waste to landfills. Authorities of the investigated areas are committed to maintaining sound and healthy greener environment by involving various CBOs, NGOs, local clubs. Proper solid waste collection is important for the protection of public health, safety, and environmental quality. However, it is high time to rethink about solid waste collection, management and incineration practices for the welfare of the nation as well as to protect the world. The results of Focus group discussions (FGD) and Key Informants Interviews (KII) are discussed elsewhere.

\section{Recommendations}

A sound and healthy knowledge regarding the solid wastes characterization before disposal is important for the management of MSW. When planning storage places for hazardous chemical waste, the characteristics of the specific chemicals to be stored and disposed of must be considered (i.e. inflammable, corrosive, explosive).

$3 \mathrm{R}$ practices for waste management technology must be implemented to reduce, reuse and recycle the waste materials of any industry to minimize hazardous toxic, construction and electronic generation in Bangladesh. Priority should be given in municipal commercial solid waste.

E-waste is known to contain certain toxic constituents in their components such as $\mathrm{Pb}, \mathrm{Cd}, \mathrm{Hg}$, polychlorinated bi-phenyls (PCBs), etc., heavy chemicals, brominated flame retardants etc., which are required to be handled safely as; all of them are highly health hazard and belonging carcinogenic effect. By recovering those heavy metals, one can earn lots of money as they are highly costly metals.

WtE strategy will also ensure availability of cheaper and greener energy, which will certainly reduce the energy crisis problem to a certain extent and can generate green jobs. The economic life of the WtE plant is chosen considering the economic life the coal-based power plant on the ground that electricity generated will replace coal electricity. 
The legal and regulatory framework is not followed properly. Govt. of Bangladesh introduces its regulatory framework in 1996 but it could not bring any significant changes.

Budget allocation for Solid Waste Management (SWM) must be increased for the sake of minimizing environmental pollution. The waste should be preferably collected by staff wearing protective clothing, equipment and mask who are trained in safe disposal method.

Awareness rising program for waste disposal and it benefits for our economy could be focused through print, electronic and social media. City Corporation or Municipality should provide several waste disposals points to store or collect it every day.

Elimination of fossil fuels, restriction of plastics and reduction of garbage has been taken under consideration. Waste treatment plant must be provided in all concerned area by virtue of making a clean and greener city.

Waste Concern is among the very few organizations conducted research and implementing small-scale replications of municipal solid waste management projects in close partnership with the Government all over the country. Much more research and monitoring should be taken in consideration for productive industrial involvement.

All households will be encouraged to purchase and use compost bins available in the market. As part of the strategy, the City Corporations or Pauroshava will provide market information; negotiate with the suppliers and arrange for higher purchase systems; and also develop appropriate subsidies for the poorer sections to obtain the bins that will be effective for the livelihood for the poorest people of the locality.

\section{Acknowledgements}

The authors would like to express their deepest gratitude to Almighty Allah and extend their heartfelt appreciation to Bogura Municipality officials, Chattogram City Corporation and other agency owners and workers for their cooperation, giving valuable information, comments and suggestions.

\section{Conflicts of Interest}

The authors declare no conflicts of interest regarding the publication of this paper.

\section{References}

[1] Hoornweg, D. and Bhada-Tata, P. (2012) What a Waste: A Global Review of Solid Waste Management. Urban Development \& Local Government Unit, World Bank, Washington DC, USA.

[2] Chowdhury, R.B., Sujauddin, M., Murakami, S. Chakraborty, P. and Alam, M.S. (2013) Current Status of Municipal Solid Waste Management System in Chittagong, Bangladesh. International Journal of Environment and Waste Management, 12, 167-188. https://doi.org/10.1504/IJEWM.2013.055592 
[3] Nazmul Islam, K.M. (2016) Municipal Solid Waste to Energy Generation in Bangladesh: Possible Scenarios to Generate Renewable Electricity in Dhaka and Chittagong City. Journal of Renewable Energy, 2016, Article ID: 1712370. https://doi.org/10.1155/2016/1712370

[4] Environmental Protection Agency (2012) Definition of Solid Waste Context: Protection of Environment. Chapter-I (Continued). Subchapter-I Solid Wastes (Continued). Part 261-Identification and Listing of Hazardous Waste. Subpart-A General) Vol. 27. Section 261.2.

[5] BMDF (2012) Study on Municipal Solid Waste Management for Chittagong City Corporation, Rajshahi City Corporation, Rangpur Municipality and Patuakhali $\mathrm{Mu}$ nicipality. Bangladesh Municipal Development Fund (BMDF), 21 June 2012, 26-83.

[6] Alamgir, M. and Ahsan, A. (2007) Municipal Solid Waste and Recovery Potential: Bangladesh Perspective. Iranian Journal of Environmental Health Science \& Engineering, 4, 67-76.

[7] Ashraf, M.A., Islam, M.R. and Adnan, S.G. (2015) GIS and Multi Criteria Decision Method Based Approach of Identifying Appropriate Landfill Sites for the City of Chittagong. International Journal of Environment, 4, 1-15. https://doi.org/10.1016/j.wasman.2015.08.018

[8] Welivita, I., Wattage, P. and Gunawardena, P. (2015) Review of Household Solid Waste Charges for Developing Countries-A Focus on Quantity-Based Charge Methods. Waste Management, 46, 637-645. https://doi.org/10.1016/j.wasman.2015.08.018

[9] Uddin, S.M.K., Afroz, M., Saifullah, I. and Rashid, M.H. (2011) Effect of Tyre Dust on the Strength of Concrete. Proceedings of the 2nd International Conference on Waste Safe, Khulna, 13-15 February 2011.

[10] Ahsan, N. and Nasim, N. (2019) Bogura Earns Brand Name for Farm Machineries. Dhaka Tribune, Published, $10.49 \mathrm{pm}$.

[11] Islam, K.M.N. (2018) Municipal Solid Waste to Energy Generation: An Approach for Enhancing Climate Co-Benefits in the Urban Areas of Bangladesh. Renewable \& Sustainable Energy Reviews, 81, 2472-2486. https://doi.org/10.1016/j.rser.2017.06.053

[12] Bahauddin, K.M. and Uddin, M.H. (2012) Prospect of Solid Waste Situation and An Approach of Environmental Management Measure (EMM) Model for Sustainable Solid Waste Management: Case Study of Dhaka City. Journal of Environmental Science and Natural Resources, 5, 99-111. https://doi.org/10.3329/jesnr.v5i1.11601

[13] Samiul Islam, F.A. (2016) Solid Waste Management System in Dhaka City of Bangladesh. Journal of Modern Science and Technology, 4, 192-209.

[14] Enayetullah, I., Khan, S.S.A. and Sinha, A.H.M.M. (2005) Urban Solid Waste Management Scenario of Bangladesh: Problems and Prospects. Waste Concern, Dhaka, Bangladesh.

[15] Ahsan, A., Alamgir, M., El-Sergany, M.M., Shams, S., Rowshon, M.K. and Daud, N.N. (2014) Assessment of Municipal Solid Waste Management System in a Developing Country. Chinese Journal of Engineering, 2014, Article ID: 561935.

[16] Menikpura, N., Sang-Arun, J. and Bengtsson, M. (2013) Integrated Solid Waste Management: An Approach for Enhancing Climate Co-Benefits through Resource Recovery. Journal of Cleaner Production, 58, 34-42. https://doi.org/10.1016/j.jclepro.2013.03.012

[17] Abedin, M.A. and Jahiruddin, M. (2015) Waste Generation and Management in 
Bangladesh: An Overview. Asian Journal of Medical and Biological Research, 1, 114-120. https://doi.org/10.3329/ajmbr.v1i1.25507

[18] Waste Concern (2009) Waste Database of Bangladesh. http://www.wasteconcer.org/

[19] Ahsan, A., Alamgir, M., Imteaz, M.A., Shams, S., Rowshon, M.K. and Aziz, M.G. (2015) Municipal Solid Waste Generation, Composition and Management: Issues and Challenges. A Case Study. Environmental Protection Engineers, 41, 43-58. https://doi.org/10.37190/epe150304

[20] Lundgren, K. (2012) The Global Impact of e-Waste: Addressing the Challenge. International Labor Organization.

https://www.ilo.org/wcmsp5/groups/public/---ed dialogue/---sector/documents/pu blication/wcms 196105.pdf

[21] Ashikuzzaman, M. and Howlader, M. (2019) Sustainable Solid Waste Management in Bangladesh: Issues and Challenges. https://doi.org/10.4018/978-1-7998-0198-6.ch002

[22] Nathanson, J.A. (2020) Solid-Waste Management. https://www.britannica.com/technology/solid-waste-management

[23] Adam Voiland, Design by Joshua Stevens. Introduction Global View, Local Sources Variations in the Trend, The Shale Revolution Arctic Permafrost Gas Hydrates, The Future of Methane, 8 March 2016.

https://earthobservatory.nasa.gov/features/MethaneMatters

[24] Hasan, M.K., Shahriar, A. and Jim, K.U. (2019) Water Pollution in Bangladesh and Its Impact on Public Health. Heliyon, 5, e02145.

https://doi.org/10.1016/j.heliyon.2019.e02145

[25] Banglapedia (2014) National Encyclopedia of Bangladesh. http://www.banglapedia.org/HT/B 0348.htm

[26] Alam, O., Hossain, M. and Al-Mamun, M.A. (2015) An Investigation into the Green Business Opportunity for the New Entrepreneurs in the Municipal Wastes Recycling Sector of Bangladesh. Proceedings of the 4th International Conference on Waste Safe, Khulna, 15-17 February 2015.

[27] Herat, S. and Agamuthu, P. (2012) E-Waste: A Problem or an Opportunity? Review of Issues, Challenges and Solutions in Asian Countries. Waste Management \& Research, 30, 1113-1129. https://doi.org/10.1177/0734242X12453378

[28] Mazumder, L.T., Hasan, S. and Rahman, M.L. (2013) Hexavalent Chromium in Tannery Solid Waste Based Poultry Feed in Bangladesh and Its Transfer to Food Chain. IOSR Journal of Environmental Science, Toxicology and Food Technology, 3, 44-51. https://doi.org/10.9790/2402-0344451

[29] Themelis, N.J. and Kim, H.Y. (2002) Material and Energy Balances in Large Scale Aerobic Bioconversion Cell. Waste Management \& Research, 20, 234-242. https://doi.org/10.1177/0734242X0202000304

[30] Anukam, A., Mohammadi, A., Naqvi, M. and Granström, K. (2019) A Review of the Chemistry of Anaerobic Digestion: Methods of Accelerating and Optimizing Process Efficiency. Processes, 7, 504. https://doi.org/10.3390/pr7080504

[31] Abdel-Shafy, H.I. and Mansour, M.S.M. (2018) Solid Waste Issue: Sources, Composition, Disposal, Recycling, and Valorization. Egyptian Journal of Petroleum, 27, 1275-1290. https://doi.org/10.1016/j.ejpe.2018.07.003

[32] Themelis, N.J. and Ulloa, P.A. (2007) Methane Generation in Landfills, Earth Engineering Center and Department of Earth and Engineering, Renewable Energy, 32, 1243-1257. https://doi.org/10.1016/j.renene.2006.04.020 
[33] Bhakov, Z.K., Korazbekova, K.U. and Lakhanova, K.M. (2014) The Kinetics of Methane Production from Co-Digestion of Cattle Manure. Pakistan Journal of Biological Sciences, 17, 1023-1029. https://doi.org/10.3923/pjbs.2014.1023.1029

[34] Md. Zohur-uz-zaman and Riyad, A.S.M.(2014) Sustainable Management Scheme for Academic Institutional Solid Waste: A Case Study in Khulna Metropolitan City, Bangladesh. International Journal of Computer Applications, 91, 21-26.

[35] Salequzzaman, M., Sultana, U.T. and Hoque, M.A. (2006) Ecological Footprint of Waste Generation: A Sustainable Tool for Solid Waste Management of Khulna City Corporation of Bangladesh. Proceedings of International Conference on Complex Systems, Boston, 25-30 June 2006.

[36] Salam, M.A., Hossain, M.L., Das, S.R., Wahab, R. and Hossain, M.K. (2012) Generation and Assessing the Composition of Household Solid Waste in Commercial Capital City of Bangladesh. International Journal of Environmental Science and Technology, 1, 160-171.

[37] Sujauddin, M., Huda, S.M.S. and Hoque, A.T.M.R. (2008) Household Solid Waste Characteristics and Management in Chittagong, Bangladesh. Waste Management, 28, 1688-1695. https://doi.org/10.1016/j.wasman.2007.06.013

[38] Ahmed, A.A.M., Ahmed, A.A.M., Alam, M.J.B. and Tithi, A.G. (2010) Solid Waste Management through Bartering-A Case Study in Sylhet. Proceedings of International Conference on Environmental Aspects of Bangladesh, September, Japan.

[39] Tan, S.T., Hashim, H., Lim, J.S., Ho, W.S., Lee, C.R. and Yan, J. (2014) Energy and Emission Benefits of Renewable Energy Derived from Municipal Solid Waste: Analysis of Low Carbon Scenario in Malaysia. Applied Energy, 136, 797-804. https://doi.org/10.1016/j.apenergy.2014.06.003

[40] Clarke, M. (1988) Improving Environmental Performance of MSW Incinerators. INFORM, New York.

[41] Kader, M.A., Das, B.K. and Mustafi, N.N. (2013) Study on Energy Recovery from Municipal Solid Waste by Gasification: A Solution of Power Crisis and Environmental Pollution. Proceedings of 3rd International Conference on Waste Safe, Khulna, 10-12 February 2013.

[42] Ichord Jr., R.F. (2020) Transforming the Power Sector in Developing Countries: Geopolitics, Poverty and Climate Change in Bangladesh.

https://www.atlanticcouncil.org/in-depth-research-reports/issue-brief/transforming -the-power-sector-in-developing-countries-geopolitics-poverty-and-climate-change -in-bangladesh

[43] Department for Environment, Food \& Rural Affairs (2011) Government Review of Waste Policy in England.

https://www.gov.uk/government/publications/government-review-of-waste-policy-i n-england-2011

[44] Islam, K.M.N. and Jashimuddin, M. (2017) Reliability and Economic Analysis of Moving towards Wastes to Energy Recovery-Based Waste Less Sustainable Society in Bangladesh: The Case of Commercial Capital City Chittagong. Sustainable Cities and Society, 29, 118-129. https://doi.org/10.1016/j.scs.2016.11.011 


\section{Abbreviations}

\begin{tabular}{cc}
\hline GHGs & Green House Gases \\
OFMSW & Organic Fraction of Municipal Solid Waste \\
LFG & Landfill Gas \\
REP & Renewable Energy Potential \\
MSW & Municipal solid waste \\
OSW & Organic Solid Waste \\
FGD & Focus Group Discussion \\
KII & Key Informants Interviews \\
LHV & Lower Heating Value \\
VFW & Vegetables for Food Wastes \\
WtE & Waste to Energy. \\
SDGs & Sustainable Development Goals \\
SWDS & Solid Waste Disposal Services \\
HSW & Household Solid Waste \\
E-Waste & Electronic Waste \\
CBOs & Community Based Organizations \\
\hline
\end{tabular}

